\title{
Patch-test results in children and adolescents: systematic review of a 15-year period ${ }^{*}$
}

\author{
Dulcilea Ferraz Rodrigues ${ }^{1}$
}

Eugênio Marcos Andrade Goulart ${ }^{2}$

DOI: http:/ /dx.doi.org/10.1590/abd1806-4841.20163927

\begin{abstract}
The number of studies on patch-test results in children and adolescents has gradually increased in recent years, thus stimulating reviews. This paper is a systematic review of a 15-year period devoted to studying the issue. Variations pertaining to the number and age groups of tested children and/or adolescents, the number of subjects with atopy/atopic dermatitis history, the quantity, type and concentrations of the tested substances, the test technique and type of data regarding clinical relevance, must all be considered in evaluating these studies, as they make it harder to formulate conclusions. The most common allergens in children were nickel, thimerosal, cobalt, fragrance, lanolin and neomycin. In adolescents, they were nickel, thimerosal, cobalt, fragrance, potassium dichromate, and Myroxylon pereirae. Knowledge of this matter aids health professionals in planning preventive programs aimed at improving children's quality of life and ensuring that their future prospects are not undermined.
\end{abstract}

Keywords: Adolescent; Allergens; Child; Dermatitis; Dermatitis, allergic contact; Dermatitis, contact; Patch-tests

\section{INTRODUCTION}

The increase in the number of published studies on patch-test results in children and adolescents has contributed vast knowledge on the subject and shown that contact sensitization (or contact allergy) and allergic contact dermatitis (ACD) are not uncommon in childhood or adolescence, contrary to what was believed. ${ }^{1}$

Most of these studies were based on selected populations: children and adolescents with suspected ACD, many with a diagnosis of atopic dermatitis (AD). There are few studies that examine the general population. ${ }^{2,3}$ Many papers present contact sensitization frequency data, without data on the positive tests' clinical relevance or conclusions on ACD frequency. 2,4,5 The higher frequency of positive patchtests in children aged under 3 years has indicated that contact sensitization may occur early in life. The association between atopy and ACD has been studied and still presents controversial results. ${ }^{2}$

Dermatologists, pediatricians and allergologists pursue a valuable interest in identifying the substance causing ACD, differentiating it from other dermatoses and identifying the possible coexistence of AD and ACD in patients.

Nowadays, children and adolescents frequently use cosmetics (fragrances, makeup, nail polish, etc.) and adornments (Henna tattoo, jewelry, piercing, etc.) that can be sources of potential allergens. ${ }^{6-10}$ Therefore, it is justifiable to expect a higher number of positive reactions to patch-tests among these age groups.

The objective of this study is to perform a systematic review, gathering and synthesizing information about patch-test results in children and adolescents published during a 15-year period, thus enhancing our knowledge. 


\section{MATERIALS AND METHODS}

A literature search to find descriptors for this systematic review was undertaken via six databases: BVS COCHRANE, BVS LILACS, BVS IBECS, BVS MEDLINE, Web of Science and PUBMED. It used the following terms: patch-test, contact sensitization, contact allergy, contact hyper sensitization, allergic contact dermatitis, and contact eczema. Filters were placed for age (children and/or adolescents aged up to 19 years; classification adopted by the World Health Organization), study period (January 1997 to May 2012) and language (Portuguese, English and Spanish). A study was selected with patients aged up to 20 years, taking into account the sample size $(n=2340)$ and lack of Asian studies in this review.

Seventy articles were picked out. All the data about the subjects' characteristics and patch-test results from 48 articles were recorded and catalogued in specific forms, which were divided into three categories:

1. Studies with selected samples (34): patients with suspected ACD.

2. Studies with no selected samples (2): children and/or adolescents with no suspected ACD.

3. Studies with selected (9) and non-selected (3) samples with specific focus.

Categories 1 and 2 include articles presenting samples of at least 50 children and/or adolescents, in addition to data on the frequency results of tested substances. Category 3 includes specific articles, with greater flexibility regarding the data.

\section{STUDIES IN SELECTED SAMPLES: PATIENTS WITH SUSPECTED ALLERGIC CONTACT DERMATITIS \\ 1.Country, period, number of centers and delineation of studies}

The data were organized according to the study period intending the evaluation of the tests results temporal evolution (Table 1).

Twenty-two studies were carried out in Europe, five in the USA, one in the USA and Canada, one in Canada, two in Brazil, two in Asia and one in Africa. ${ }^{11-44}$

Only three studies were performed in more than three centers; twenty-four were carried out at only one center. ${ }^{11-44}$

Regarding the delineation, twenty-six studies were based on retrospective data, while eight were prospective. ${ }^{11-44}$

2.Research subjects: sample size and selection, age, sex, atopy history, dermatitis location and duration

The number of patients was below 200 in 20 studies and a maximum of 100 in $10 .{ }^{11-44}$
In the 34 studies, tests were carried out in patients with suspected ACD but half of these involved a significant percentage of patients (over 30.0\%) with $\mathrm{AD}$ or atopy history. 12,13,15,19-22,25,26,29,31,33-35,41,43,44 In 13 studies, there was monitoring of Hanifin and Rajka criteria for this diagnosis. ${ }^{45}$ In some studies, all subjects with suspected ACD presented an AD diagnosis, compared with only a small percentage in others (below 30.0\%). 14,28,32,38,39 In 2 studies, patients presented chronic recalcitrant eczematous dermatitis or severe AD. ${ }^{32,35}$

Children and adolescents of varying ages and age groups were examined; one study included exclusively children aged 3-36 months ${ }^{33}$, whereas another included adolescents. ${ }^{25}$

Regarding gender, females were predominant in 25 studies and males were predominant in 2.11-44

As for dermatitis evolution prior to testing, a study revealed that $80.0 \%$ of dermatitis cases had durations of over three months. ${ }^{25}$

The body sites most affected by dermatitis were: the face and hands, followed by the feet, generalized dermatitis, the legs and neck. ${ }^{14-16,18-20,23-26,29,39}$

\section{Technique:}

Batteries were used in six pediatric studies: 17 substances for children under 5 years; ${ }^{21} 30$ substances for children under 10 years; ${ }^{22}$ pediatric series of 30 substances in another three studies ${ }^{33,34,36}$ and a series of 10 substances. ${ }^{40}$ Others used adult standardized batteries. ${ }^{11,12,15-21,23-26,29-32,35,37,38,41,43,44}$

The number of substances tested varied. Approximately $50.0 \%$ of these studies assessed $22-40$ substances. ${ }^{11,12,15,17-23,25,27,28,30,33,36-38,41,44}$ In one study, 25185 substances (mean: 92) were evaluated; the number was 48 or 66 in another, and 65 in one other. ${ }^{29-31}$ The smallest number of tested allergens was $10 .{ }^{40}$

Furthemore, the concentrations of some substances were also diverse: nickel (most studies: $5.0 \%$, some: $2.5 \%$ ), thimerosal (most: $0.1 \%$, some: $1.0 \%$ and $0.05 \%$ ), fragrance mix I (most: $8.0 \%$, some: $5.0 \%$, $7.0 \%, 14.0 \%$ ), potassium dichromate (most: $0.5 \%$, some: $0.25 \%$ ), cobalt (most: $1.0 \%$, one study: $0.5 \%),{ }^{40}$ Kathon CG $(2.0 \%$ and $0.5 \%) .{ }^{13,22,23,25,27,31-33,40-42}$

Most studies followed the ICDRG (International Contact Dermatitis Research Group) testing criteria. ${ }^{46}$ One study reduced the test occlusion time to 24 hours in 11 centers $^{23}$ and three increased it to 72 hours. ${ }^{12,22,27}$ Another study implemented only a 48-hour reading. ${ }^{29}$ There was no active sensitization and the number of irritant reactions was small in the Manzini study. ${ }^{12}$

Data about the tests' clinical relevance are presented below. 
TABLE 1 : Patch-test results in selected groups of children and adolescents with suspected allergic contact dermatitis (34 selected groups)

\begin{tabular}{|c|c|c|c|c|c|c|}
\hline $\begin{array}{l}\text { Author } \\
\text { Country }\end{array}$ & $\begin{array}{l}\text { Data } \\
\text { Collection, } \\
\text { years }\end{array}$ & $\begin{array}{l}\mathrm{N}^{\circ} \text { of children } \\
\text { and adolescents } \\
\text { tested }\end{array}$ & Age & $\begin{array}{l}\text { Adolescents and } \\
\text { children with } \\
>1 \text { positive } \\
\text { reaction }(\%)\end{array}$ & $\begin{array}{l}\text { Relevance* } \\
\text { of positive tests } \\
(\%)\end{array}$ & $\begin{array}{l}\text { Two most } \\
\text { common allergens } \\
\text { Frequency of } \\
\text { positive reactions }\end{array}$ \\
\hline $\begin{array}{l}\text { Goon et al. }{ }^{11} \\
\text { Singapore }\end{array}$ & 1986-2003 & 2340 & $<20$ years & 45.4 & $\begin{array}{l}\text { Calculated per } \\
\text { substance }\end{array}$ & $\begin{array}{l}\text { Nickel } 40.0 \% \\
\text { Thimerosal } 15.0 \%\end{array}$ \\
\hline $\begin{array}{l}\text { Manzini et al. }{ }^{12} \\
\text { Italy }\end{array}$ & 1988-1994 & 670 & $\begin{array}{l}6 \text { months- } \\
12 \text { years }\end{array}$ & 42.0 & not reported & $\begin{array}{l}\text { Thimerosal 12.2\% } \\
\text { Nickel 7.7\% }\end{array}$ \\
\hline $\begin{array}{l}\text { Brash et al. }{ }^{13} \\
\text { Germany }\end{array}$ & 1990-1995 & 416 & $6-15$ years & 40.9 & not reported & $\begin{array}{l}\text { Nickel 15.9\% } \\
\text { Thimerosal 11.3\% }\end{array}$ \\
\hline $\begin{array}{l}\text { Fernandez et al. }{ }^{14} \\
\text { Spain }\end{array}$ & $1990-2000$ & 96 & $<15$ years & 54.2 & 57.7 & $\begin{array}{l}\text { Thimerosal 21.0\% } \\
\text { Mercury } 19.0 \%\end{array}$ \\
\hline $\begin{array}{l}\text { Shah et al. }{ }^{15} \\
\text { UK }\end{array}$ & 1991-1995 & 83 & $6-16$ years & 49.0 & 100.0 & $\begin{array}{l}\text { Nickel } 14.0 \% \\
\text { Fragrance mix I 7.2\% }\end{array}$ \\
\hline $\begin{array}{l}\text { Romaguera et al. }{ }^{16} \\
\text { Spain }\end{array}$ & 1992-1997 & 141 & $<14$ years & 50.0 & $\begin{array}{l}\text { calculated per } \\
\text { substance }\end{array}$ & $\begin{array}{l}\text { Nickel 19.1\% } \\
\text { Cobalt 11.3\% }\end{array}$ \\
\hline $\begin{array}{l}\text { Lewis et al.17 } \\
\text { UK }\end{array}$ & 1993-2003 & 191 & $<16$ years & 41.0 & 51.7 & $\begin{array}{l}\text { Nickel 13.0\% } \\
\text { Fragrance mix I 9.0\% }\end{array}$ \\
\hline $\begin{array}{l}\text { Onder et al. }{ }^{18} \\
\text { Turkey }\end{array}$ & 1993-2005 & 360 & 2-16 years & 32.0 & $30.5 \%$ & $\begin{array}{l}\text { Nickel } 46.0 \% \\
\text { Cobalt } 9.5 \%\end{array}$ \\
\hline $\begin{array}{l}\text { Milingou et al. }{ }^{19} \\
\text { Greece }\end{array}$ & 1994-2007 & 255 & $<16$ years & 60.0 & not reported & $\begin{array}{l}\text { Nickel 21.6\% } \\
\text { Thimerosal 18.3\% }\end{array}$ \\
\hline $\begin{array}{l}\text { Kuljanac et al. }{ }^{20} \\
\text { Croatia }\end{array}$ & 1994-2009 & 412 & 4-18 years & 26.0 & not reported & $\begin{array}{l}\text { Nickel } 25.4 \% \\
\text { Thimerosal 17.8\% }\end{array}$ \\
\hline $\begin{array}{l}\text { Roul et al. }{ }^{21} \\
\text { France }\end{array}$ & 1995-1997 & 337 & $1-15$ years & 67.0 & not reported & $\begin{array}{l}\text { Nickel 23.7\% } \\
\text { Fragrance mix I 9.5\% }\end{array}$ \\
\hline $\begin{array}{l}\text { Seidenari et al. }{ }^{22} \\
\text { Italy }\end{array}$ & 1995-2001 & 1094 & $\begin{array}{l}7 \text { months- } \\
12 \text { years }\end{array}$ & 52.1 & 70.0 & $\begin{array}{l}\text { Neomycin } 13.2 \% \\
\text { Nickel } 10.9 \%\end{array}$ \\
\hline $\begin{array}{l}\text { Heine et al. }{ }^{23} \\
\text { Germany }\end{array}$ & 1995-2002 & 2460 & $\begin{array}{l}6-12 \text { years } \\
13-18 \text { years }\end{array}$ & $\begin{array}{l}52.6 \\
49.7\end{array}$ & $\begin{array}{l}\text { not reported } \\
\text { not reported }\end{array}$ & $\begin{array}{l}\text { Thimerosal } 18.2 \% \\
\text { Nickel } 16.7 \%\end{array}$ \\
\hline $\begin{array}{l}\text { Clayton et al. }{ }^{24} \\
\text { UK }\end{array}$ & 1995-2004 & 500 & $<16$ years & 27.0 & 61.0 & $\begin{array}{l}\text { Nickel } 33.0 \% \\
\text { Fragrance mix I 18.0\% }\end{array}$ \\
\hline $\begin{array}{l}\text { Duarte et al. }{ }^{25} \\
\text { Brazil }\end{array}$ & 1996-2001 & 102 & 10-19 years & 56.0 & 100.0 & $\begin{array}{l}\text { Nickel } 31.0 \% \\
\text { Tosylamide } 12.0 \% \dagger\end{array}$ \\
\hline $\begin{array}{l}\text { Hogeling et al. }{ }^{26} \\
\text { Canada }\end{array}$ & 1996-2006 & 100 & 4-18 years & 70.0 & 55.8 & $\begin{array}{l}\text { Nickel } 26.0 \% \\
\text { Cobalt } 14.0 \%\end{array}$ \\
\hline $\begin{array}{l}\text { Wöhrl et al. }{ }^{27} \\
\text { Austria }\end{array}$ & $1997-2000$ & 79 & $1-10$ years & 62.0 & not reported & $\begin{array}{l}\text { Nickel 34.2\% } \\
\text { Ethylmercury 25.3\% }\end{array}$ \\
\hline $\begin{array}{l}\text { Giordano et al. }{ }^{28} \\
\text { France }\end{array}$ & not reported & 137 & $\begin{array}{l}4 \text { months- } \\
16 \text { years }\end{array}$ & 43.0 & 100.0 & $\begin{array}{l}\text { Nickel } 14.9 \% \\
\text { Fragrance mix I } 4.4 \%\end{array}$ \\
\hline $\begin{array}{l}\text { Beattie et al. }{ }^{29} \\
\text { UK }\end{array}$ & 1999-2002 & 114 & $3-15$ years & 54.0 & 54.0 & $\begin{array}{l}\text { Nickel } 20.0 \% \\
\text { Fragrance mix I } 7.2 \%\end{array}$ \\
\hline $\begin{array}{l}\text { Hammonds et al. }{ }^{30} \\
\text { USA }\end{array}$ & $2000-2006$ & 136 & 3-18 years & 61.0 & 53.0 & $\begin{array}{l}\text { Nickel } 22.0 \% \\
\text { Cobalt } 17.0 \%\end{array}$ \\
\hline $\begin{array}{l}\text { Zug et al. }{ }^{31} \\
\text { USA, Canada }\end{array}$ & 2001-2004 & 391 & $0-18$ years & 65.7 & $51.2 \S$ & $\begin{array}{l}\text { Nickel } 28.3 \% \\
\text { Cobalt } 17.8 \%\end{array}$ \\
\hline $\begin{array}{l}\text { Jacob et al. } .^{32} \\
\text { USA }\end{array}$ & 2001-2006 & 65 & 1-18 years & 83.0 & 77.0 & $\begin{array}{l}\text { Nickel 17.5\% } \\
\text { Thimerosal } 12.5 \%\end{array}$ \\
\hline $\begin{array}{l}\text { Fortina et al. }{ }^{33} \\
\text { Italy }\end{array}$ & $2002-2008$ & 321 & 3-36 months & 62.3 & $\begin{array}{l}\text { calculated per } \\
\text { substance }\end{array}$ & $\begin{array}{l}\text { Nickel } 26.8 \% \\
\text { Potassium dich.9.0\% }\end{array}$ \\
\hline
\end{tabular}


TABLE 1 (CONTINUED): Patch-test results in selected groups of children and adolescents with suspected allergic contact dermatitis (34 selected groups)

\begin{tabular}{|c|c|c|c|c|c|c|}
\hline $\begin{array}{l}\text { Author } \\
\text { Country }\end{array}$ & $\begin{array}{l}\text { Data } \\
\text { Collection, } \\
\text { years }\end{array}$ & $\begin{array}{l}\mathrm{N}^{\mathrm{o}} \text { of children } \\
\text { and adolescents } \\
\text { tested }\end{array}$ & Age & $\begin{array}{l}\text { Adolescents and } \\
\text { children with } \\
>1 \text { positive } \\
\text { reaction }(\%)\end{array}$ & $\begin{array}{l}\text { Relevance* } \\
\text { of positive tests } \\
(\%)\end{array}$ & $\begin{array}{l}\text { Two most } \\
\text { common allergens } \\
\text { Frequency of } \\
\text { positive reactions }\end{array}$ \\
\hline $\begin{array}{l}\text { Moustafa et al. }{ }^{34} \\
\text { UK }\end{array}$ & 2002-2008 & 110 & $2-18$ years & 44.0 & 44.0 & $\begin{array}{l}\text { Drugs } 15.4 \% \\
\text { Nickel } 10.0 \%\end{array}$ \\
\hline $\begin{array}{l}\text { de Waard-van } \\
\text { der Spek et al. }{ }^{35} \\
\text { Netherlands }\end{array}$ & 2003-2008 & 79 & $1-18$ years & 51.0 & $\begin{array}{l}\text { calculated per } \\
\text { substance }\end{array}$ & $\begin{array}{l}\text { Nickel 21.5\% } \\
\text { Potassium dich. } 6.0 \% \mid\end{array}$ \\
\hline $\begin{array}{l}\text { Jacob et al. }{ }^{36} \\
\text { USA }\end{array}$ & 2004-2006 & 69 & $\begin{array}{l}6 \text { months- } \\
18 \text { years }\end{array}$ & 95.6 & 76.7 & $\begin{array}{l}\text { Nickel 23.3\% } \\
\text { Cocamido 23.3\% }\end{array}$ \\
\hline $\begin{array}{l}\text { Stoskute et al. }{ }^{37} \\
\text { Lithuania }\end{array}$ & not reported\# & 194 & 3-17 years & 55.0 & not reported & $\begin{array}{l}\text { Nickel } 18.0 \% \\
\text { Cobalt } 13.8 \%\end{array}$ \\
\hline $\begin{array}{l}\text { Belhadjalli et al. }{ }^{38} \\
\text { Tunisia }\end{array}$ & 2005-2006 & 63 & $\begin{array}{l}\text { mean: } \\
69 \text { months }\end{array}$ & 39.7 & $38.2 \S$ & $\begin{array}{l}\text { Nickel } 24.7 \% \\
\text { Potassium dich. } 7.9 \% \mid\end{array}$ \\
\hline $\begin{array}{l}\text { Sarma et al. }{ }^{39} \\
\text { India }\end{array}$ & $2005-2008$ & 70 & $1-15$ years & 80.0 & 60.7 & $\begin{array}{l}\text { Paraben } 43.0 \% \\
\text { Potassium dich. } 27.0 \%\end{array}$ \\
\hline $\begin{array}{l}\text { Czarnobilska et al. }{ }^{40} \\
\text { Poland }\end{array}$ & 2007 & 229 & $\begin{array}{l}7 \text { years } \\
16 \text { years }\end{array}$ & $\begin{array}{l}43.8 \\
52.6\end{array}$ & $\begin{array}{l}\text { not reported } \\
\text { not reported }\end{array}$ & $\begin{array}{l}\text { Nickel } 30.2 \% \\
\text { Thimerosal } 27.8 \%\end{array}$ \\
\hline $\begin{array}{l}\text { Kobata }^{41} \\
\text { Brazil }\end{array}$ & 2007-2009 & 62 & 2-12 years & 61.0 & 70.0 & $\begin{array}{l}\text { Nickel } 27.4 \% \\
\text { Thimerosal } 17.7 \%\end{array}$ \\
\hline $\begin{array}{l}\text { Czarnobilska et al. }{ }^{42} \\
\text { Poland }\end{array}$ & 2008-2009 & 196 & $\begin{array}{l}7-8 \text { years } \\
16-17 \text { years }\end{array}$ & $\begin{array}{l}67.0 \\
58.1\end{array}$ & $\begin{array}{l}\text { not reported } \\
\text { not reported }\end{array}$ & $\begin{array}{l}\text { Nickel 35.9\% } \\
\text { Thimerosal 37.6\% }\end{array}$ \\
\hline $\begin{array}{l}\text { Jacob et al. }{ }^{43} \\
\text { USA }\end{array}$ & 2008-2009 & 102 & $6-18$ years & 76.2 & not reported & $\begin{array}{l}\text { Nickel } 29.7 \% \\
\text { p-tert-Butylphenol 16.8\%** }\end{array}$ \\
\hline $\begin{array}{l}\text { Herro et al. }{ }^{44} \\
\text { USA }\end{array}$ & not reportedtt & 101 & 6-18 years & 78.0 & not reported & $\begin{array}{l}\text { Nickel } 31.0 \% \\
\text { Lanolin } 18.0 \%\end{array}$ \\
\hline
\end{tabular}

*Relevance: current and/or past; †tosylamide formaldehyde resin; łcloreto ethylmercuric chloride; §calculated from number of tested patients; | potassium dichromate; ๆcocamidopropyl betaine; \#published in 2005; **p-tert-Butylphenol formaldehyde resin;†tpublished in 2011.

\section{Response to patch-tests}

- Relationship with age

Seven studies showed no difference in contact sensitization regarding age $\mathrm{e}^{23,26,29,30,32,33,39}$ but three found a greater frequency of positive tests in older age groups: 11-15 years, 12 years, $15-16$ years. ${ }^{11,19,24}$ In addition, two studies showed higher sensitization rates in children aged over 5 and $6 .^{28,35}$ Despite the link found between increased contact sensitization indicators and older ages, three studies revealed higher sensitization rates among children under $3.12,21,22$

\section{- Relationship with gender}

Three studies showed a significant difference regarding the relationship between contact sensitization frequency and gender: two with a higher frequency among girls ${ }^{19,24}$ and one among boys. ${ }^{33}$ However, there were five studies that revealed no differences in this respect. $13,22,26,30,39$ In addition, five studies demonstrated differences concerning only certain allergens: nickel (more frequent among girls), nickel and cobalto and other substances. . $^{14,16,28,29,42}$

\section{- Relationship with atopy}

There was no statistically significant difference regarding contact sensitization among atopic and non-atopic patients in nine studies. . $^{14,20-22,25,26,28,31,33}$ In contrast, four studies did reveal a significant difference. ${ }^{13,24,39,44}$ In three studies, all the patients under study had $\mathrm{AD}$, thus making assessment impossible, though one of them showed higher sensitization rates in severe $\mathrm{AD}(60.9 \%)$ than in the moderate $(37.5 \%)$ and mild $(30.0 \%)$ forms. ${ }^{28,32,38}$ One study compared a group of children and adolescents with $\mathrm{AD}$ to a healthy group of adolescents (asymptomatic), demonstrating contact sensitization frequencies of $55.0 \%$ and $15.0 \%$, respectively ${ }^{37}$ Other studies presented data on atopy, 
without statistical data on the association. dermatitis

- Relationship with body sites affected by

The body sites most frequently affected by dermatitis in patients with positive tests were: the trunk, followed by the face, hands, feet and generalized dermatitis. ${ }^{12,14,22,24,33}$

\section{- Relationship with allergen sources}

There was a significant association between mercapto mix and plantar eczema in one study. ${ }^{24}$ Footwear was considered a source of rubber derivatives, formaldehyde, potassium dichromate and metallic mercury. ${ }^{14,15,19}$ Sports equipment was regarded as sources of rubber derivatives, while "natural" cosmetics were considered sources of propolis. ${ }^{17,22}$

- Relationship with the first site of dermatitis

One study showed that the initial site of the most common dermatitis in positive tests was the palm region (33.0\%), followed by the plantar region $(29.0 \%)$ and legs $(29.0 \%)$. But there was no statistically significant difference in the relationship between the first site of dermatitis and the positive result of contact testing. ${ }^{24}$

Two studies reported that the initial dermatitis site did not match any specific allergen. ${ }^{24,26}$ Except for the involvement of the ears, which is characteristic of sensitization by nickel, no other body site has been related to a specific allergen. ${ }^{12}$

\section{- Relationship with occupation and polysensitization}

The few reports regarding occupation were on: hairdressers, construction workers, health professionals and metallurgical workers. ${ }^{14-16,19,23}$

Six studies presented data on polysensitization, with the following, respective frequency rates: $42.0 \%$, $29.6 \%, 19.6 \%, 17.8 \%$ of children undergoing tests; and $54.0 \%, 51.0 \%$ of positive test cases. $12,17,22,26,29,33$

\section{- Percentage of patients who had at least one positive reaction}

Frequency rates ranged from $26.0 \%$ to $95.6 \%$.

Thirteen studies revealed rates of below $50.0 \%$, 17 studies had frequencies ranging from $50.0 \%$ to $70.0 \%$, and 5 reported a frequency of over $70.0 \% .{ }^{11-44}$ There was the total of 35 studies as one study separated these frequencies: children and adolescents.

\section{of positive tests}

- Percentage of patients with clinical relevance

Among the studies containing data on the clinical relevance of positive tests, fifteen revealed a frequency above $50.0 \%$, of which five had an $100.0 \%$ relevance in cases of positive tests. Frequency relevance varied from $30.5 \%$ to $100.0 \%$. Four studies did not take this frequency from all positive tests; calculations were made based on the number of positive tests for each substance assessed. Two studies presented the relevance calculated only from the total number of patients undergoing tests (not from positive tests), while twelve studies presented no data on the matter. ${ }^{11-44}$

\section{- Frequency of the most common allergens}

The most common allergens in children were nickel, thimerosal, cobalt, fragrance mix I, lanolin and neomycin. In adolescents, they were nickel, thimerosal, cobalt, fragrance mix I, potassium dichromate, and balsam of Peru (Myroxylon pereirae). ${ }^{11-44}$

Nickel was the most frequent allergen in 29 studies and was placed among the 10 most common allergens in the 34 studies, with frequency varying from $7.76 \%$ to $46.0 \% .^{12,18}$

There were reports of positive reactions for cobalt as well as nickel in $68.0 \%$ and $71.0 \%$ of cases. ${ }^{26,32}$ Pure sensitization for cobalt was uncommon. ${ }^{11,25}$

Thimerosal was the most frequent substance in four studies and classed among the 10 most common allergens in 29 studies. Its frequency varied from $0.9 \%$ to $37.6 \% .33,42$

Fragrance mix I was among the 10 most frequent allergens in 28 studies, cobalt in 27 studies, neomycin in 18, potassium dichromate in 15, lanolin in 12 , balsam of Peru in 12, para-Phenylenediamine in 10, formaldehyde and rubber derivatives in 8 , colophony in 7, quaternium-15 and p-tert-Butylphenol in $6{ }^{11-44}$

Neomycin was the most common allergen in 1 study, paraben mix also in 1 and drug allergens (lanolin, quinoline mix, gentamycin, tixocortol pivalate) in another. Kathon CG, tosylamide formaldehyde resin, gold thiosulfate, disperse dyes, cocamidopropylbetaine, tixocortol pivalate, propolis and paraben mix, were also among the 10 most frequent allergen in some studies. ${ }^{12,17,22,25,26,30,32,33,34,36,38,39,43}$

Amerchol L-101 and plant allergens were ranked among the most common allergens in 1 study. ${ }^{34}$ Cocamidopropylbetaine was tested in 3 studies and the allergy contact frequency varied from $7.2 \%$ to $23.3 \% .32,33,36$

In studies that tested tixocortol pivalate, the frequency of positive reactions (among the most frequent allergens) varied from $5.0 \%$ to $7.9 \% .17,43,44$

\section{STUDIES IN NON-SELECTED SAMPLES}

A European study was carried out in 40 schools where most students had a history of $\mathrm{AD}$ and hand eczema. They assessed 1,146 adolescents aged 12- 
TABLE 2: Patch -test results in children and adolescents without suspected allergic contact dermatitis (two unselected groups)

\begin{tabular}{|c|c|c|c|c|c|c|}
\hline $\begin{array}{l}\text { Author } \\
\text { Country } \\
\mathrm{N}^{\mathrm{o}} \text { of centers }\end{array}$ & $\begin{array}{l}\text { Data } \\
\text { collection } \\
\text { years }\end{array}$ & $\begin{array}{l}\mathrm{N}^{\circ} \text { of children } \\
\text { and adolescents } \\
\text { tested }\end{array}$ & Age & $\begin{array}{l}\text { Adolescents and } \\
\text { Children with } \\
>1 \text { positive reaction } \\
(\%)\end{array}$ & $\begin{array}{l}\text { Relevance* } \\
\text { of positive } \\
\text { tests } \\
(\%)\end{array}$ & $\begin{array}{l}\text { Three most common } \\
\text { allergens. } \\
\text { Frequency of positive } \\
\text { reactions }\end{array}$ \\
\hline $\begin{array}{l}\text { Mortz et al. }{ }^{45} \\
\text { Denmark } \\
40 \text { centers }\end{array}$ & 1995-1996 & 1146 & $\begin{array}{l}12-16 \\
\text { years }\end{array}$ & 15.2 & 47.7 & $\begin{array}{l}\text { Nickel } 8.6 \% \\
\text { Fragrance mix I 1.8\% } \\
\text { Cobalt } 1.0 \% \\
\text { Thimerosal } 1.0 \%\end{array}$ \\
\hline $\begin{array}{l}\text { Bruckner et al. }{ }^{46} \\
\text { USA } \\
1 \text { center }\end{array}$ & $\begin{array}{l}\text { not } \\
\text { reported } \dagger\end{array}$ & 85 & $\begin{array}{l}6 \text { months- } \\
5 \text { years }\end{array}$ & 24.5 & not reported & $\begin{array}{l}\text { Nickel } 12.9 \% \\
\text { Thimerosal } 9.4 \% \\
\text { Kathon CG 2.4\% } \\
\text { Neomycin } 1.2 \%\end{array}$ \\
\hline
\end{tabular}

*Relevance: current and/or past; †published in 2000; ¥methylchloroisothiazolinone/methylisothiazolinone

16 years using the TRUE test and nickel in three concentrations (Table 2). ${ }^{47}$

An American study evaluated 95 asymptomatic children of both sexes, aged between 6 months and 5 years, via the TRUE test. ${ }^{48}$

\section{Response to patch-tests}

In the European study, there were significantly more female adolescents with positive tests. No association emerged between contact sensitization and $\mathrm{AD}$, though there was a significant association between contact sensitization and hand eczema. Reactions to two or more allergens were reported in $14.9 \%$ of the adolescents. The relevance frequency of positive tests was $47.7 \%{ }^{47}$

In the American study, $45.0 \%$ of children with positive tests were aged under 18 months. ${ }^{48}$

Patients with at least one positive reaction to the patch-test had the following frequency rates: $15.2 \%$ of adolescentes and $24.5 \%$ of children undergoing tests. ${ }^{47,48}$

The most common allergens in these two studies were nickel. Nickel, cobalt, thimerosal, and p-tert-butylphenol were among the six most frequent allergens. ${ }^{47,48}$

\section{STUDIES IN SELECTED SAMPLES (9) AND NON-SELECTED SAMPLES (3) WITH SPECIFIC FOCUS}

Preservatives were tested in 811 children (566 with AD) and $7.27 \%$ of the children had at least one positive reaction to a preservative: imidazolidinylurea, diazolidinylurea, paraben mix, formaldehyde, quaternium 15, Euxyl K 400, Kathon CG (methylcloroisothiazolinone/ methylizothiazolinone), butylated hydroxyanisole. Kathon CG was the most frequent and quaternium 15 entailed no positive reactions, thus emphasizing the importance of patch-tests for preservatives in children with eczema and/or AD.49

An investigation of 2,482 children and adolescents (0-19 years) showed a frequency variation for fragrance mix of $2.5-3.4 \%$, with a lower frequency among those aged $0-9$ years. ${ }^{50}$

Allergy to cosmetics occurred in $21(30.0 \%)$ children out of 70, aged 1-15 years, followed by topical medication, metals and rubber derivatives. ${ }^{51}$

One study demonstrated a higher proportion of very strong reactions $(3+)$ to the paraphenylenediamine in patch-tests among children aged up to 14 years, compared with other age groups and other tested allergens (nickel, fragrance mix I and Kathon CG). It was suggested that the concentration of para-phenylenediamine for testing should be reduced for children with a history of allergy to hair dyes and/ or Henna tattoos. ${ }^{52}$

In a study of 641 children with $\mathrm{AD}$ diagnoses, the contact sensitization frequency to AD topical treatments was $6.2 \%$. The risk factors associated with contact sensitization to AD topical treatments were: disease seriousness (more frequent in moderate to severe $A D$ ), early $A D$ onset (before 6 months) and sensitization mediated by IgE. The most frequent sensitizers were antiseptics (chlorhexidene) and emollients (particularly vegetal protein extracts and fragrances). The authors suggested including antiseptics and emollients in the contact test battery for children with AD and suspected ACD. In addition, they recommended using emollients devoid of fragrances and vegetal protein extracts. ${ }^{53}$ 
The ISAAC (International Study of Asthma and Allergies in Childhood) undertook a study of 143 children, concluding that every case of recurrent chronic dermatitis in children requires differential diagnosis of ACD with other dermatoses (AD, etc.), even if they are predominantly located in the flexural areas. ${ }^{54}$

A multicentric study of 111 children with hand eczema revealed frequencies of $46.8 \%$ (contact allergy) and $36.0 \%$ (ACD). Nickel, fragrances and Kathon CG were the most common allergens. It was recommended that patch-testing be performed on any child with chronic hand eczema. ${ }^{55}$

One study tested 1,255 children with suspected ACD, using propolis at $20.0 \%$. The frequency for positive reactions was $5.9 \%$ of cases. It was suggested that propolis should not be used as a constituent of topical products for children. ${ }^{56}$

In another study, 1,098 children were tested with 30 substances, including dyes: 5 disperse dyes in 964 and 7 disperse dyes in 134 children. Further, 4.6\% had positive tests, involving at least 1 disperse dye, the most common being: disperse yellow 3, disperse orange 3 , disperse blue 124, disperse red 1 and p-dimethylaminoazobenzene. ${ }^{57}$

Two studies of non-selected samples tested only metals, while one tested just nickel and fragrance mix. ${ }^{58-60}$ A study showed that children with pierced ears were more likely to react to nickel that those without, revealing a nickel frequency of $20.0 \% .^{60}$ The frequency of positive tests for fragrance mix I in children aged under 18 months was low. ${ }^{59}$ Another study showed that $18.2-29.6 \%$ of positive reactions to patch-tests for nickel would not be detected with only a 48 -hour reading. ${ }^{58}$

\section{DISCUSSION}

Contact testing seems to be as important in children (even those aged under 3 years) as in adolescents, since contact sensitization occurs in every age group, though sensitization frequencies vary according to the specific age group. ${ }^{12,21,22,48}$ Importantly, age-related variations occur only in relation to some allergens. ${ }^{14,31,40,42}$

Females were predominant among the tested patients but there was no consensus regarding contact sensitization and gender. ${ }^{19,22,24,26,30,33,39}$

The association between atopy and contact sensitization remains a point of contention. 13,14,20-22,24-29,31-33,37-39,44

ACD diagnoses depend on correct technique procedures and reading and interpretation of patchtests. In some studies, there was variation in the occlusion period and reading, which may have influenced patch-test results (false-positives and falsenegatives). ${ }^{12,13,22,23,27,29}$
In the thirty-four studies on selected samples, contact sensitization frequency varied from $26.0 \%$ to $95.6 \%$ and in the two studies on non-selected samples, the range was $15.2-24.5 \%$, showing that the rate changed according to the type of sample assessed. ${ }^{11-44,47,48}$ Studies with frequencies of over $70.0 \%$ used more extensive batteries; one was composed of

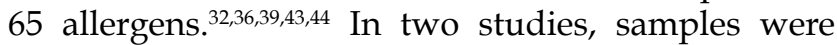
composed $70.0 \%$ and $50.0 \%$ respectively of children with a history of $\mathrm{AD} .{ }^{32,36,44}$ In the three studies with lower frequencies for positive tests, the batteries used were less extensive. ${ }^{20,24,38}$ In two of these, $43.0 \%$ and $100.0 \%$ of the patients had AD. ${ }^{20,38}$

Some substance concentrations varied, which may have affected the frequency of contact sensitization.

Nickel revealed significant frequency variation: $7.76-46.0 \%$ in thirty-four studies across selected samples; and $8.6-20.0 \%$ in three studies of nonselected samples. ${ }^{12,18,58-60}$ Most tested nickel at 5.0\% but three assessed it at $2.5 \% .^{31,40,42}$ The sensitization frequency for thimerosal varied from $0.9 \%$ to $37.6 \%$. Its lowest frequency occurred in a study where the concentration was $0.1 \%$ whereas its highest frequency occurred when tested at $1.0 \%{ }^{13,33,42}$ In four studies, the concentration was $0.05 \% .{ }^{13,25,27,41}$ Most studies deemed that thimerosal had no clinical relevance.

Regarding studies with propolis, sensitization frequency varied from $0.74 \%$ to $16.5 \%$ in selected samples but the substance was tested at $10.0 \%$ in one study and at $20.0 \%$ in two. ${ }^{12,22,42,56}$

Drawing on studies involving disperse dyes in children, the frequency of positive reactions varied as follows: disperse blue 106 (2.98-16.3\%); disperse blue 124 (1.27-3.1\%); disperse red $1(0.72-2.8 \%)$ and disperse yellow $3(0.54-1.9 \%) .32,33,36,57$

Some authors have recommended using pediatric batteries including emollients, antisseptics, preservatives, propolis and fragrance mix II, as well as smaller chambers in the adhesives of childrens' tests. ${ }^{12,21,28,42,49,53,61}$

Nickel was the most frequent allergen in children and adolescents, followed by thimerosal, fragrance mix I, cobalt, neomycin, potassium dichromate, lanolin, para-phenylenediamine, formaldehyde and rubber derivatives. ${ }^{11-44}$

The clinical relevance of positive tests is important in interpreting patch-test results, as this enables the differentiation of ACD and contact sensitization. ${ }^{10,46}$ Important data on clinical relevance include: type (current, past), frequency calculated for positive tests and frequency calculated for each substance.

It is important the physician, the parents and the patient interests in relating a substance identified in the test to the patient's current dermatitis 
and to the allergen source, not limited only to the identification of contact sensitization, thus making possible the ACD treatment and the recurrence prevention. ${ }^{62}$ Furthermore, monitoring patients after patch-testing is important as regards clinical relevance and treatment evaluation. ${ }^{15,28,34,36}$

Patch-tests are an effective method for identifying the causative agent of $A C D$, inducing the type IV immune reaction in children and adolescents, as it comes about in adults. . $3,64,65$ Experience is necessary to undertake selection of patients and substances relevant to these patients' problems. ${ }^{66}$ The conclusion was that a clinic specialized in patch-testing can detect more ACD cases than a non-specialized one ${ }^{67}$

Preventive measures can be taken, as has occurred in many countries. ${ }^{68,69}$ Furthermore, educational programs can be implemented and directed towards physicians, pregnant women, children and their families, in order to provide guidance on the importance of avoiding contact with allergens in childhood, especially metals and fragrances in atopic children. ${ }^{37,44,70}$

\section{CONCLUSION}

The most common allergens in children were nickel, thimerosal, cobalt, fragrance mix, lanolin and neomycin. In adolescents, they were nickel, thimerosal, cobalt, fragrance mix, potassium dichromate, and Myroxylon pereirae. The following also featured among the 10 most frequent allergens in some studies, representing emerging allergens: Kathon CG, tosylamide formaldehyde resin, gold thiosulfate, disperse dyes, cocamidopropylbetaine, tixocortol pivalate and propolis. This knowledge is important when considering preventive measures.

Since they make it difficult to draw conclusions, variations in the following factors must be taken into account when evaluating the studies: the number and age groups of children and/or adolescents tested, the number of subjects with a history of atopy/atopic dermatitis, the quantity, type and concentration of tested substances, the test techniques and type of data with clinical relevance.

Given the difficulty in comparing the results of the study on patch-tests due to regional differences regarding exposure to allergens, as well as the aforementioned factors, an evidence-based, standardized database is needed.]

\section{REFERENCES}

1. Bonitsis NG, Tatsioni A, Bassioukas K, Ioannidis JP. Allergens responsible for allergic contact dermatitis among children: a systematic review and metaanalysis. Contact Dermatitis. 2011;64:245-57.

2. Mortz CG, Andersen KE. Allergic contact dermatitis in children and adolescents. Contact Dermatitis. 1999;41:121-30.

3. Spiewak R. Allergic contact dermatitis in childhood - a review and meta-analysis. Allergologie. 2002;25:374-81.

4. Sharma VK, Asati DP. Pediatric contact dermatitis. Indian J Dermatol Venereol Leprol. 2010;76:514-20.

5. Castanedo-Tardan MP, Matiz C, Jacob SE. Contact dermatitis in children - a review of current opinions. Actas Dermosifiliogr. 2011;102:8-18.

6. Lee PW, Elsaie ML, Jacob SE. Allergic contact dermatitis in children: common allergens and treatment: a review. Curr Opin Pediatr. 2009;21:491-8.

7. Militello G, Jacob SE, Crawford GH. Allergic contact dermatitis in children.Curr Opin Pediatr. 2006;18:385-90.

8. Storrs FJ. Patch testing children--what should we change? Pediatr Dermatol. 2008;25:420-3.

9. Pigatto P, Martelli A, Marsili C, Fiocchi A. Contact dermatitis in children. Ital J Pediatr. 2010;36:2.

10. Czarnobilska E, Dyga W, Krzystyniak D, Czarnobilski K, Myszkowska D, Obtułowicz K. Influence of environment exposures on the frequency of contact allergies in children and adolescents. Ann Agric Environ Med. 2012;19:11-6.

11. Goon AT, Goh CL. Patch testing of Singapore children and adolescents: our experience over 18 years. Pediatr Dermatol. 2006;23:117-20.

12. Manzini BM, Ferdani G, Simonetti V, Donini M, Seidenari S. Contact sensitization in children. Pediatr Dermatol. 1998;15:12-7.

13. Brasch J, Geier J. Patch test results in schoolchildren. Results from the Information Network of Departments of Dermatology (IVDK) and the German Contact Dermatitis Research Group (DKG). Contact Dermatitis. 1997;37:286-93.

14. Fernández Vozmediano JM, Armario Hita JC. Allergic contact dermatitis in children. J Eur Acad Dermatol Venereol. 2005;19:42-6.

15. Shah M, Lewis FM, Gawkrodger DJ. Patch testing in children and adolescents: five years' experience and follow-up. J Am Acad Dermatol. 1997;37:964-8.

16. Romaguera C, Vilaplana J. Contact dermatitis in children: 6 years' experience (1992-1997). Contact Dermatitis. 1998;39:277-80.

17. Lewis VJ, Statham BN, Chowdhury MM. Allergic contact dermatitis in 191 consecutively patch tested children. Contact Dermatitis. 2004;51:155-6.
18. Onder M, Adisen E. Patch test results in a Turkish paediatric population. Contact Dermatitis. 2008;58:63-5.

19. Milingou M, Tagka A, Armenaka M, Kimpouri K, Kouimintzis D, Katsarou A. Patch tests in children: a review of 13 years of experience in comparison with previous data. Pediatr Dermatol. 2010;27:255-9.

20. Kuljanac I, Knežević E, Cvitanović $H$. Epicutaneous patch test results in children and adults with allergic contact dermatitis in Karlovac county: a retrospective survey. Acta Dermatovenerol Croat. 2011;19:91-7.

21. Roul S, Ducombs G, Taieb A. Usefulness of the European standard series for patch testing in children. A 3-year single-centre study of 337 patients. Contact Dermatitis. 1999;40:232-5.

22. Seidenari S, Giusti F, Pepe P, Mantovani L. Contact sensitization in 1094 children undergoing patch testing over a 7-year period. Pediatr Dermatol. 2005;22:1-5.

23. Heine G, Schnuch A, Uter W, Worm M. Frequency of contact allergy in German children and adolescents patch tested between 1995 and 2002: results from the Information Network of Departments of Dermatology and the German Contact Dermatitis Research Group. Contact Dermatitis. 2004;51:111-7.

24. Clayton TH, Wilkinson SM, Rawcliffe C, Pollock B, Clark SM. Allergic contact dermatitis in children: should pattern of dermatitis determine referral? A retrospective study of 500 children tested between 1995 and 2004 in one U.K. centre. Br J Dermatol. 2006;154:114-7.

25. Duarte I, Lazzarini R, Kobata CM. Contact Dermatitis in Adolescents. Am J Contact Dermat. 2003;14:200-2.

26. Hogeling M, Pratt M. Allergic contact dermatitis in children: the Ottawa Hospita patch-testing clinic experience, 1996 to 2006. Dermatitis. 2008;19:86-9.

27. Wöhrl S, Hemmer W, Focke M, Götz M, Jarisch R. Patch testing in children, adults, and the elderly: influence of age and sex on sensitization patterns. Pediatr Dermatol. 2003;20:119-23.

28. Giordano-Labadie F, Rancé F, Pellegrin F, Bazex J, Dutau G, Schwarze HP. Frequency of contact allergy in children with atopic dermatitis: results of a prospective study of 137 cases. Contact Dermatitis. 1999;40:192-5.

29. Beattie PE, Green C, Lowe G, Lewis-Jones MS. Which children should we patch test? Clin Exp Dermatol. 2007;32:6-11.

30. Hammonds LM, Hall VC, Yiannias JA. Allergic contact dermatitis in 136 children patch tested between 2000 and 2006. Int J Dermatol. 2009 ;48:271-4.

31. Zug KA, McGinley-Smith D, Warshaw EM, Taylor JS, Rietschel RL, Maibach HI, et al. Contact allergy in children referred for patch testing: North American Contact 
Dermatitis Group data, 2001-2004. Arch Dermatol. 2008;144:1329-36.

32. Jacob SE, Brod B, Crawford GH. Clinically relevant patch test reactions in childrena United States based study. Pediatr Dermatol. 2008;25:520-7.

33. Belloni Fortina A, Romano I, Peserico A, Eichenfield LF. Contact sensitization in very young children. J Am Acad Dermatol. 2011;65:772-9.

34. Moustafa M, Holden CR, Athavale P, Cork MJ, Messenger AG, Gawkrodger DJ. Patch testing is a useful investigation in children with eczema. Contact Dermatitis. 2011;65:208-12.

35. de Waard-van der Spek FB, Oranje AP. Patch tests in children with suspected allergic contact dermatitis: a prospective study and review of the literature. Dermatology. 2009;218:119-25.

36. Jacob SE, Yang A, Herro E, Zhang C. Contact allergens in a pediatric population: association with atopic dermatitis and comparison with other north american referral centers. J Clin Aesthet Dermatol. 2010;3:29-35.

37. Stoskute L, Dubakiene R, Tamosiunas V. Allergic contact dermatitis and patch testing in children. Acta Medica Lituanica. 2005;12:71-4.

38. Belhadjali H, Mohamed M, Youssef M, Mandhouj S, Chakroun M, Zili J. Contact sensitization in atopic dermatitis: results of a prospective study of 89 cases in Tunisia. Contact Dermatitis. 2008;58:188-9.

39. Sarma N, Ghosh S. Clinico-allergological pattern of allergic contact dermatitis among 70 Indian children. Indian J Dermatol Venereol Leprol. 2010;76:38-44.

40. Czarnobilska E, Obtulowicz K, Dyga W, Wsolek-Wnek K, Spiewak R. Contact hypersensitivity and allergic contact dermatitis among school children and teenagers with eczema. Contact Dermatitis. 2009;60:264-9

41. Kobata CM. Testes de contato em crianças com eczema [dissertação]. São Paulo (SP): Universidade de São Paulo; 2010.79p

42. Czarnobilska E, Obtulowicz K, Dyga W, Spiewak R. The most important contact sensitizers in Polish children and adolescents with atopy and chronic recurrent eczema as detected with the extended European Baseline Series. Pediatr Allergy Immunol. 2011;22:252-6.

43. Jacob SE, Herro EM, Sullivan K, Matiz C, Eichenfield L, Hamann C. Safety and efficacy evaluation of TRUE TEST panels 1.1, 2.1, and 3.1 in children and adolescents. Dermatitis. 2011;22:204-10.

44. Herro EM, Matiz C, Sullivan K, Hamann C, Jacob SE. Frequency of contact allergens in pediatric patients with atopic dermatitis. J Clin Aesthet Dermatol. 2011:4:39-41.

45. Hanifin JM, Rajka G. Diagnostic features of atopic dermatitis. Acta Dermatol Venereol 1980; 92:44-47.

46. Spiewak R. Patch testing for contact allergy and allergic contact dermatitis. Open Allergy J. 2008;1:42-51.

47. Mortz CG, Lauritsen JM, Bindslev-Jensen C, Andersen KE. Contact allergy and allergic contact dermatitis in adolescents: prevalence measures and associations. The Odense Adolescence Cohort Study on Atopic Diseases and Dermatitis (TOACS). Acta Derm Venereol. 2002;82:352-8.

48. Bruckner AL, Weston WL, Morelli JG. Does sensitization to contact allergens begin in infancy? Pediatrics. 2000;105:e3.

49. Conti A, Motolese A, Manzini BM, Seidenari S. Contact sensitization to preservatives in children. Contact Dermatitis. 1997;37:35-6.

50. Buckley DA, Rycroft RJ, White IR, McFadden JP. The frequency of fragrance allergy in patch-tested patients increases with their age. Br J Dermatol. 2003;149:986-9.

51. Kohl L, Blondeel A, Song M. Allergic contact dermatitis from cosmetics Retrospective analysis of 819 patch-tested patients. Dermatology. 2002;204:334-7.

52. Spornraft-Ragaller $P$, Schnuch $A$, Uter $W$. Extreme patch test reactivity to p-phenylenediamine but not to other allergens in children. Contact Dermatitis. 2011; 65:220-6.

53. Mailhol C, Lauwers-Cances V, Rancé F, Paul C, Giordano-Labadie F. Prevalence and risk factors for allergic contact dermatitis to topical treatment in atopic dermatitis: a study in 641 children. Allergy. 2009;64:801-6.

54. Czarnobilska E, Obtulowicz K, Dyga W, Spiewak R. A half of schoolchildren with 'ISAAC eczema' are ill with allergic contact dermatitis. J Eur Acad Dermato Venereol. 2011;25:1104-7.

55. Toledo F, García-Bravo B, Fernández-Redondo V, De la Cuadra J, Giménez-Arnau $\mathrm{AM}$, Borrego L, et al. Patch testing in children with hand eczema. A 5-year multicentre study in Spain. Contact Dermatitis. 2011;65:213-9.

56. Giusti F, Miglietta R, Pepe P, Seidenari S. Sensitization to propolis in 1255 children undergoing patch testing. Contact Dermatitis. 2004;51:255-8.

57. Giusti F, Massone F, Bertoni L, Pellacani G, Seidenari S. Contact sensitization to disperse dyes in children. Pediatr Dermatol. 2003;20:393-7.
58. Thyssen JP, Jensen CS, Johansen JD, Menné T. Results from additional nickel patch test readings in a sample of schoolgirls from the general population. Contact Dermatitis. 2008;59:317-8.

59. Jøhnke $H$, Norberg LA, Vach W, Bindslev-Jensen C, Høst A, Andersen KE. Reactivity to patch tests with nickel sulfate and fragrance mix in infants. Contact Dermatitis. 2004;51:141-7.

60. Brandão $\mathrm{MH}$, Gontijo $\mathrm{B}$, Girundi $\mathrm{MA}$, de Castro MC. Ear piercing as a risk factor for contact allergy to nickel. J Pediatr (Rio J). 2010;86:149-54.

61. Jacob SE, Steele T, Brod B, Crawford GH. Dispelling the myths behind pediatric patch testing-experience from our tertiary care patch testing centers. Pediatr Dermatol. 2008;25:296-300.

62. Bruckner AL, Weston WL. Allergic contact dermatitis in children: a practical approach to management. Skin Therapy Lett. 2002;7:3-5.

63. Duarte I, Lazzarini R, Buense R, Pires MC. Contact dermatitis. An Bras Dermatol. 2000; 75:529-48.

64. Hennino A, Vocanson M, Chavagnac C, Saint-Mezard P, Dubois B, Kaiserbian D, et al. Update on the pathophysiology with special emphasis on CD8 effector T cells and CD4 regulatory T cells. An Bras Dermatol. 2005; 80:334-47.

65. Martins LE, Reis VM. Immunopathology of allergic contact dermatitis. An Bras Dermatol. 2011:86:419-33.

66. van der Valk PG, Devos SA, Coenraads PJ. Evidence-based diagnosis in patch testing. Contact Dermatitis. 2003:48:121-5.

67. Ormond P, Hazelwood E, Bourke B, Lyons JF, Bourke JF. The importance of a dedicated patch test clinic. Br J Dermatol. 2002;146:304-7.

68. Thyssen JP, Johansen JD, Carlsen BC, Menné T. Prevalence of nickel and cobalt allergy among female patients with dermatitis before and after Danish government regulation: a 23-year retrospective study. J Am Acad Dermatol. 2009;61:799-805.

69. Jensen CS, Lisby S, Baadsgaard 0, Vølund A, Menné T. Decrease in nickel sensitization in a Danish schoolgirl population with ears pierced after implementation of a nickel-exposure regulation. Br J Dermatol. 2002;146:636-42.

70. Kütting B, Brehler R, Traupe H. Allergic contact dermatitis in children - strategies of prevention and risks management. Eur J Dermatol. 2004;14:80-5.

\author{
MAILING ADDRESS: \\ Dulcilea Ferraz Rodrigues \\ Av. Bernardo Monteiro, 890, sala 603 \\ Bairro Santa Efigênia \\ 30150-281 - Belo Horizonte - MG \\ Brazil \\ E-mail: dulcilea.ferraz@gmail.com
}

How to cite this article: Rodrigues DF, Goulart EMA. Patch-test results in children and adolescents: systematic review of a 15-year period. An Bras Dermatol. 2016;91(1):64-72. 